\title{
4 Altitudinal Zonation of Montane Oak Forests Along Climate and Soil Gradients in Costa Rica
}

\author{
M. Kappelle and J.-G. VAn Uffelen
}

\subsection{Introduction}

Altitudinal forest zonation along tropical environmental gradients has fascinated scientists since Alexander von Humboldt's fabulous journey to tropical America at the beginning of the 19th Century (Von Humboldt and Bonpland $1808)$. Since Cuatrecasas' $(1934,1958)$ mid-20th Century accounts on altitudinal zonation of Andean forests, numerous scholars have attempted to understand the patterns and causes of forest zonation on wet tropical mountains (Grubb and Whitmore 1966; Whitmore and Burnham 1969; Holdridge et al. 1971; Flenley 1974; Ellenberg 1975; Lauer 1976; Grubb 1977; Tanner 1977; van der Hammen et al. 1983, 1989a; Ohsawa et al. 1985; Gentry 1988; Marrs et al. 1988; Kitayama 1992; Bruijnzeel et al. 1993; Kitayama and Mueller-Dombois 1994a, b; Kappelle and Zamora 1995; Kappelle et al. 1995a; Vitousek et al. 1995a, b; Lieberman et al. 1996; Pendry and Proctor 1997).

Still today, researchers keep wondering about the underlying causes of floristic zonation in the humid tropics, principally paying attention to climatic and edaphic factors governing biological patterns, and the responses of vegetation and individual plant species to those factors (e.g., Bruijnzeel and Veneklaas 1998; Tanner et al. 1998; Vázquez and Givnish 1998; Aiba and Kitayama 1999; Leuschner 2000; Kitayama and Aiba 2002; Ashton 2003; Kappelle 2004).

\subsection{Altitudinal Transect Study}

\subsubsection{Sample Plots}

During the last 20 years, the first author and colleagues conducted vascular plant inventories in more than 100 rectangular montane oak forest plots (size: $0.1 \mathrm{ha}$ ) at elevations of 1,800-3,400 m above sea level (a.s.l.) along the Pacific 
Ecological Studies Vol 185, Kappelle (Ed.) - page proofs by F. Kröner, HD

and Atlantic slopes of Costa Rica's Talamancan mountain range (Kappelle et al. 1989, 1991, 1994, 1995a, b, 2000; Kappelle 1991, 1996; Kappelle and Zamora 1995; Oosterhoorn and Kappelle 2000; Chaps. 10, 15 and 17). Twenty-four of those plots were located in old-growth oak-bamboo forest at 2,000-3,200 m along the slopes of the 3,819-m-high massif of the Chirripó National Park, which is part of the Amistad Biosphere Reserve and has been declared a World Heritage Site, a Center of Plant Diversity, and an Endemic Bird Area (Kappelle and Zamora 1995; Kappelle et al. 1995a; Kappelle 1996). Results from the analysis of these 24 plots are presented here.

Plots of 0.05 ha $(20 \times 25 \mathrm{~m})$ were located at altitudinal intervals of $100 \mathrm{~m}$ and mapped on topographic sheets (scale: 1:50,000), following van der Hammen et al. (1989b). Twelve plots were located along the Pacific slope, close to the 'Fila Cementerio de la Máquina' trail to Chirripó's summit; another 12 plots were established along the Atlantic slope, near the 'Camino de los Indios' trail in the northern sector of the park.

\subsubsection{Climate Measurements}

Along the Pacific slope trail, daily courses of air temperature and relative humidity were measured at $1.3 \mathrm{~m}$ above the forest floor (breast height), under a closed canopy in lower montane $(2,000 \mathrm{~m})$ and upper montane $(2,700 \mathrm{~m})$ oak forest. Measurements were done during the 1989 rainy and 1990 dry season, using two Lambrecht thermo-hygrographs installed on a provisional wooden table with a plastic roof and all sides completely open. Additionally, at each altitudinal interval of $100 \mathrm{~m}$, temperatures were measured in top and sub-soils at intervals of $10-\mathrm{cm}$ soil depth, using a digital Consort T 550 thermometer. Averages of hourly recordings (7 days) of air temperature and relative humidity were plotted in diurnal thermo-hygrograms following Ellenberg (1975), and presented in Kappelle et al. (1995a).

\subsubsection{Soil Analysis}

Following Sevink (1984), soil pits were dug under a closed oak forest canopy at regular altitudinal intervals of $200 \mathrm{~m}$. Soil profiles were described in accordance with FAO (1977). Detailed accounts on soil analysis techniques and full descriptions of soil profiles, humus horizons, soil fauna, texture, organic matter, acidity, cation exchange capacity (CEC), base saturation and dry bulk densities can be found in van Uffelen (1991) and Kappelle et al. (1995a). 
Ecological Studies Vol 185, Kappelle (Ed.) - page proofs by F. Kröner, HD

Altitudinal Zonation of Montane Oak Forests Along Climate and Soil Gradients

\subsubsection{Forest Inventory and Community Analysis}

In each plot, all terrestrial vascular plant species were collected (Kappelle 1991). Epiphytic vascular plants were collected up to $2.5 \mathrm{~m}$ above the forest floor. Vouchers were identified and stored at herbaria in Costa Rica (CR), The Netherlands (ASD, U), and the USA (F, MO, NY, US). Bryophytes and lichens were collected, identified, and stored in Costa Rica (CR) and Germany (B, GOET), and have been dealt with elsewhere (Kappelle and Sipman 1992; Kappelle 1996; Holz et al. 2002, Chaps. 6 and 7).

Species' growth forms were recorded, and aerial crown or shoot cover projection estimated (Braun-Blanquet 1965; Mueller-Dombois and Ellenberg 1974). Average height and cover of forest layers was estimated, and average height of canopy tree layers was measured with a clinometer. Forest structure (tree stem density and relative abundance) was analyzed for stems $\geq 10 \mathrm{~cm}$ DBH (diameter at breast height), which were identified, recorded and mapped (Kappelle et al. 1995a).

Using the TWINSPAN software (Jongman et al. 1987), a polythetic divisive classification was undertaken on the data matrix (presence/absence and species-cover data), comprising 24 plots and containing 431 species, each of which occurred in at least two plots. In this way, oak forest communities and their ecological species groups were distinguished and described (Kappelle et al. 1995a).

\subsection{Altitudinal Oak Forest Zonation}

\subsubsection{Plant Species Richness}

In Chirripó's 24 oak forest plots, over 3,000 botanical specimens were collected (Kappelle 1991). Identification resulted in 431 species of mainly terrestrial vascular plants: 86 pteridophytes, one gymnosperm, 296 dicots, and 48 monocots (Kappelle et al. 1995a). Table 4.1 presents the most speciose families and genera. Five families were represented by 20 or more species, and four genera were found with 10 or more congeners. Average species richness decreased with increasing altitude, from 73 per plot in lower montane forest to 51 in upper montane forest (Fig. 4.1). Most species-rich was a Pacific plot at 2,200 m a.s.l. (97 spp.), and most species-poor a Pacific plot at 3,000 m (42 spp.). Altitudinal ranges and vernacular names of trees, shrubs, bamboos, climbers and ferns, as well as changes in woody species diversity along the altitudinal gradient have been treated elsewhere (Kappelle et al. 1991; Kappelle and Gómez 1992; Kappelle and Zamora 1995). 
Ecological Studies Vol 185, Kappelle (Ed.) - page proofs by F. Kröner, HD

Table 4.1. Most diverse families and genera of terrestrial vascular plants found in the montane oak forests of Costa Rica's Chirripó National Park. Numbers of species are given within brackets

\begin{tabular}{ll}
\hline Families & Genera \\
\hline Rubiaceae (26) & Peperomia (17) \\
Piperaceae (21) & Elaphoglossum (16) \\
Asteraceae (20) & Miconia (12) \\
Melastomataceae (20) & Grammitis (11) \\
Polypodiaceae (20) & Solanum (9) \\
Ericaceae (17) & Ocotea (8) \\
Lomariopsidaceae (17) & Palicourea (8) \\
Solanaceae (16) & Asplenium (8) \\
Lauraceae (15) & Anthurium (6) \\
Myrsinaceae (13) & \\
Araceae (11) & \\
\hline
\end{tabular}

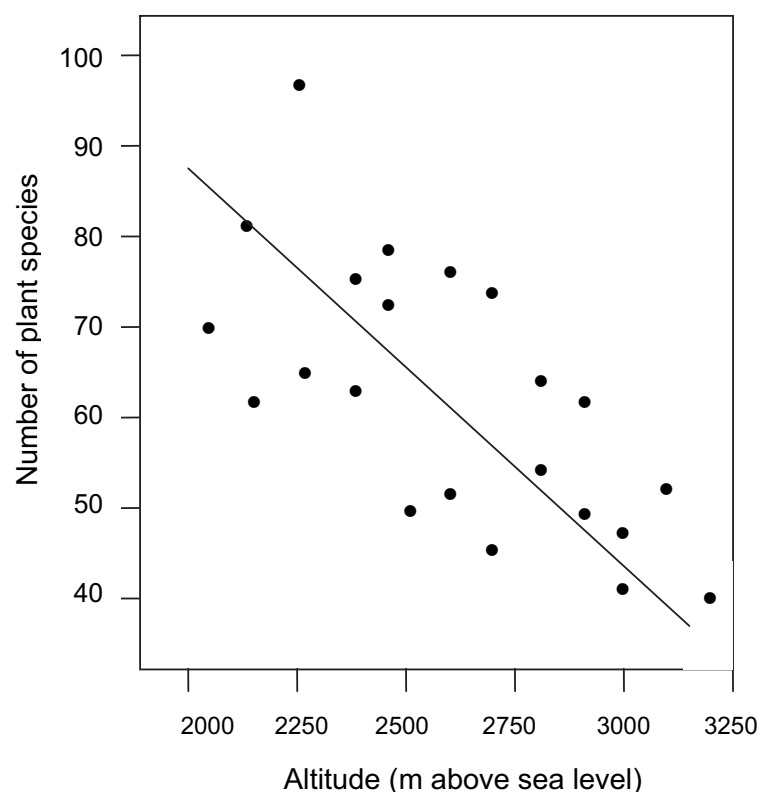

Fig. 4.1. Decrease of vascular plant species richness with altitude in montane oak forest in the Chirripó National Park, Costa Rica. Dots represent species numbers at 22 0.05-ha forest plots

\subsubsection{Forest Layering}

The average height of the canopy and subcanopy layers decreases from lower to upper montane forest, whereas the stature of the shrub, herb, and bryophyte layers remains similar (Table 4.2). This suggests a telescope-like compaction and lowering of forest structure layers at higher elevations (Kap- 
Ecological Studies Vol 185, Kappelle (Ed.) - page proofs by F. Kröner, HD

Altitudinal Zonation of Montane Oak Forests Along Climate and Soil Gradients

Table 4.2. Mean maximum height and cover of forest structure layers for montane oldgrowth oak forest communities found in the Chirripó National Park, Costa Rica. Roman numbers refer to the communities described in Kappelle et al. (1995a)

\begin{tabular}{lllllllll}
\hline Zone & LM & LM & LM & LM & UM & UM & UM & UM \\
Slope & Pac & Pac & Atl & Atl & Atl & Atl & Pac & Pac-Atl \\
Community & I & II & III & IV & V & VI & VII & VIII \\
\hline Mean maximum height (m) & & & & & & & & \\
Canopy tree layer & & & & & & & & \\
Subcanopy tree layer & 40 & 35 & 35 & 35 & 35 & 35 & 30 & 25 \\
Shrub layer & 20 & 20 & 15 & 18 & 20 & 16 & 15 & 12 \\
Herb layer & 5 & 5 & 3 & 3 & 5 & 6 & 6 & 6 \\
Bryophyte layer & 1 & 1 & 0.5 & 1 & 1 & 1 & 1 & 1 \\
& 0.1 & 0.1 & 0.1 & 0.1 & 0.1 & 0.1 & 0.1 & 0.1 \\
Mean cover (\%) & & & & & & & & \\
Canopy tree layer & & & & & & & & \\
Subcanopy tree layer & 70 & 70 & 90 & 80 & 80 & 80 & 65 & 60 \\
Shrub layera & 60 & 55 & 60 & 60 & 50 & 45 & 50 & 65 \\
Herb layer & 60 & 75 & 85 & 75 & 40 & 90 & 90 & 70 \\
Bryophyte layer & 35 & 20 & 85 & 70 & 60 & 65 & 40 & 25 \\
& 10 & 5 & 5 & 12 & 8 & 60 & 35 & 50 \\
\hline
\end{tabular}

a The canopy tree layer corresponds to the Quercus tree layer, and the shrub layer to the Chusquea bamboo layer as defined by Blaser (1987)

pelle 2004). Average cover values fluctuate between 60 and $90 \%$ for oak-dominated canopy tree layers, and between 45 and $65 \%$ for more open subcanopy tree layers. The shrub layers are dense, and reach high cover percentages due to 6-m-tall Chusquea bamboos. The cover of the herb layer has the greatest range (20-85\%), as a consequence of locally abundant species such as Besleria formosa and Hansteinia ventricosa or Rubiaceae (Palicourea and Psychotria). The bryophytic ground cover is also very variable, which is probably caused by local differences in light regimes at the forest floor (canopy openings; see also Chap. 15). In general, the bryophyte layer is better developed in upper montane oak forest (Holz et al. 2002, Chap. 7).

\subsubsection{Tree Stem Density}

Stem densities and relative abundances of tree species $(\mathrm{DBH} \geq 10 \mathrm{~cm})$ for 0.015-ha subplots are given in Kappelle et al. (1995a; but see Chap. 10). In general, stem density does not differ significantly between lower and upper montane forest. However, a small increase in average density occurs with increasing altitude (860 stems per ha in lower montane forest vs. 1,180 stems per ha in upper montane forest). Tree density was highest at 3,200 $\mathrm{m}$ a.s.l. on the Pacific slope, where Comarostaphylis arbutoides (rel. abundance: $76.3 \%$ ) 
Ecological Studies Vol 185, Kappelle (Ed.) - page proofs by F. Kröner, HD

becomes far more abundant than Quercus costaricensis. This forest resembles the transition to (non-oak) ericaceous subalpine forest just below the upper forest line (Islebe and Kappelle 1994). At higher elevations (>3,300 m a.s.l.), oak and non-oak forest is replaced by treeless, tropical, alpine, wet bamboo paramo (Kappelle 1991; Kappelle and Horn 2005). Whereas lower montane oak forests show a relatively open and interrupted canopy layer often dominated by emerging oaks, upper montane oak forests show a shorter, more flattened canopy (see also Chap. 10). Another conspicuous feature is the abundance of palms such as Geonoma hoffmanniana (Chap. 15) and Prestoea allenii in the understorey of the lower montane forests vs. the dense clumps of Chusquea bamboos in upper montane forest communities.

\subsubsection{Classification of Montane Oak Forest Communities}

Using TWINSPAN, eight Chusquea-Quercus communities were distinguished: four lower and four upper montane communities (Kappelle et al. 1995a). Montane Chusquea-Quercus forests at Chirripó are dominated by Quercus copeyensis (now known as Q. bumelioides; K.C. Nixon, personal communication), Q. costaricensis and Q. seemannii in the canopy, and Chusquea bamboos in the understorey. Common tree species are Weinmannia pinnata and the hemiepiphytic Clusia stenophylla. Other wide-ranging trees are Saurauia veraguasensis, Prunus annularis, Styrax argenteus, Viburnum costaricanum, Ocotea pittieri, and the large-leaved Oreopanax capitatus. The woody climbers Hydrangea asterolasia and Smilax kunthii occur frequently, as does the vine Bomarea acutifolia. Among common herbs figure Alloplectus ichtyoderma, Begonia udisilvestris, and the aroid Anthurium concinnatum that occurs epiphytically as well as with ground-dwelling habits (Chap. 15). Abundant ferns are Asplenium serra, Arachniodes denticulata, Elaphoglossum firmum, and E. eximium. Epiphytic species of Anthurium, Elaphoglossum, Peperomia, and Polypodium inhabit the bases of Quercus tree trunks.

\section{Lower Montane Oak Forests}

These lauraceous-fagaceous forests occur between $(1,800) 2,000$ and 2,600 m a.s.l., and are easily recognized because of their abundance of understorey palms (Geonoma hoffmanniana (Chap. 15, Chamaedorea warszewiczii and Prestoea allenii), sometimes accompanied by the bamboo Aulonemia viscosa or the cyclanth Sphaeradenia irazuensis. Dominant trees are Quercus copeyensis, Mollinedia pinchotiana, Trichilia havanensis, Ardisia glandulosomarginata, Tovomitopsis allenii, Billia hippocastanum, Nectandra salicina, Quetzalia (Microtropis) occidentalis, Guarea tonduzii, Alchornea latifolia, Meliosma glabrata, Miconia platyphylla, Lozania mutisiana, Ocotea austinii, 
Ecological Studies Vol 185, Kappelle (Ed.) - page proofs by F. Kröner, HD

Altitudinal Zonation of Montane Oak Forests Along Climate and Soil Gradients

and O. holdridgeiana. Important herbaceous taxa (both terrestrial and epiphytic) are Monstera deliciosa and Peperomia palmana, as well as the ferns Asplenium harpeodes and Vittaria graminifolia. The climber Cissus martiniana is frequently observed.

\section{Upper Montane Oak Forests}

These myrsinaceous-fagaceous forests $(2,600-3,200 \mathrm{~m}$ a.s.l.) are characterized by an understorey that is completely dominated by bamboo (Chusquea talamancensis), accompanied by ericads such as Disterigma humboldtii, Cavendishia bracteata, Macleania rupestris, and Sphyrospermum cordifolium. In the canopy layer, oak (Q. costaricensis) is accompanied by Schefflera rodriguesiana. Subcanopy trees include Rhamnus oreodendron, Drymis granadensis, Miconia schnellii, Zanthoxylum scheryi, and Ilex pallida. The ground cover is made up of herbs (Maianthemum paniculatum, Centropogon costaricae, and Peperomia saligna), ferns (Blechnum viviparum and Elaphoglossum latifolium), and the terrestrial bromeliad Vriesea williamsii. Further details on montane oak forest structure and composition are given in Chap. 10.

\subsubsection{Climatic Changes Along Elevations and Between Seasons}

Differences between daily courses of air temperature and relative humidity in lower and upper montane forest, and between dry and wet seasons are evident (Kappelle et al. 1995a). Lower relative humidity levels and higher temperatures at noon occurred during the dry season. Temperatures were highest during the dry season in the lower montane forest interior $\left(23.2^{\circ} \mathrm{C}\right)$. The lowest temperature values occurred in upper montane forest $\left(10.8^{\circ} \mathrm{C}\right)$. This feature is confirmed by data recorded over a 43-year period at Villa Mills (3,000 $\mathrm{m}$ a.s.l.) at the western border of the Chirripó National Park (Fig. 4.2).

The greatest daily temperature fluctuations were found during the dry season in the forest interior of upper montane forest $\left(12.8-19.6{ }^{\circ} \mathrm{C}\right)$. Relative humidity values oscillated strongly during the dry seasons, and appeared more stable during the wet seasons. Again, the greatest daily fluctuations were recorded in the forest interior of upper montane forest ( 29 to $>95 \%$ ). Relative humidity reached values $>85 \%$ on almost every recorded day of any season at both altitudes. This is of vital importance to epiphytic bryophytes, which cover trunks and branches in montane oak forests (Holz et al. 2002, Chap. 7).

The diurnal climatic rhythm was less pronounced in upper montane forest. This is a well-known phenomenon in tropical montane forests (Walter 1985). 
Ecological Studies Vol 185, Kappelle (Ed.) - page proofs by F. Kröner, HD

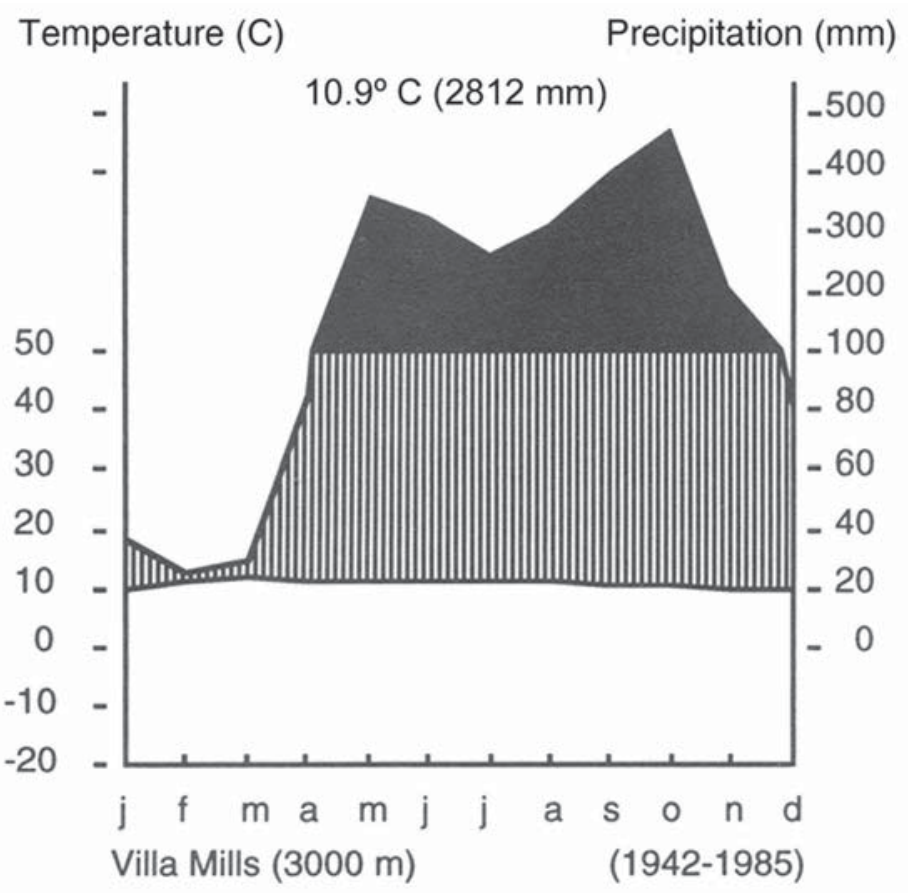

Fig. 4.2. Walter climate diagram from the Villa Mills weather station at 3,000 $\mathrm{m}$ a.s.l. in the Talamanca Mountains, west of Chirripó, Costa Rica

Measurements indicate that the average air temperature drops about $4.0^{\circ} \mathrm{C}$ with an altitudinal increase of $700 \mathrm{~m}\left(3.7^{\circ} \mathrm{C}\right.$ for wet season, and $4.2^{\circ} \mathrm{C}$ for dry season data). This implies a drop of $0.57^{\circ} \mathrm{C}$ per $100-\mathrm{m}$ increase in altitude, a value similar to that calculated for a Venezuelan montane forest (Walter 1985). Similar mean temperature drops can be derived from the subsoil temperature dataset (Kappelle et al. 1995a).

\subsubsection{Soil Genesis and Classification}

Soils under montane Quercus forests occur on moderately steep to very steep positions over both unconsolidated and consolidated substrates, and are developed in residual and colluvial material derived from parent rock (intrusive igneous and volcanic rocks). They have developed on steeply, fluvially dissected terrain, predominantly representing forms of denudational origin influenced by dendritic drainage processes. Locally, sedimentary rocks such as very fine sandstones with calcareous cement are prominent. At gently sloping, imperfectly drained positions at the Atlantic side of the mountain range, thin iron pans have formed in unconsolidated soil material derived from vol- 
Ecological Studies Vol 185, Kappelle (Ed.) - page proofs by F. Kröner, HD

Altitudinal Zonation of Montane Oak Forests Along Climate and Soil Gradients

canic rock. Organic matter accumulation is higher at the Atlantic side than along the Pacific. At both slopes, andic properties are well-developed at most places, and admixture of volcanic ash in soils is obvious. Soil acidity is very high, with $\mathrm{pH}$ values in $\mathrm{H}_{2} \mathrm{O}$ varying in the range 4.0-6.5 in the A-horizon. Base saturation is always lower than $15 \%$ for soils formed over basic or acid rock types. Following the FAO (1988) classification system, soil types under closed, old-growth montane oak forest include typic placudand; typic, alic, and acric hapludands; histic, andic, and placic humitropepts; humi-haplic, humi-umbric and humi-mollic andosols; and humi-andic dystric regosol (only at the Atlantic slope; van Uffelen 1991).

\subsubsection{Soil Changes Along Elevations and Between Slopes}

There are no specific differences in topsoil properties between lower and upper montane oak forests, though Atlantic soils appear to be slightly more clayey than Pacific soils, and their 0-horizons are significantly thicker (Fig. 4.3). In general, the very dark-brown humus profiles are often composed of fine organic material, which is free of litter fragments and may contain

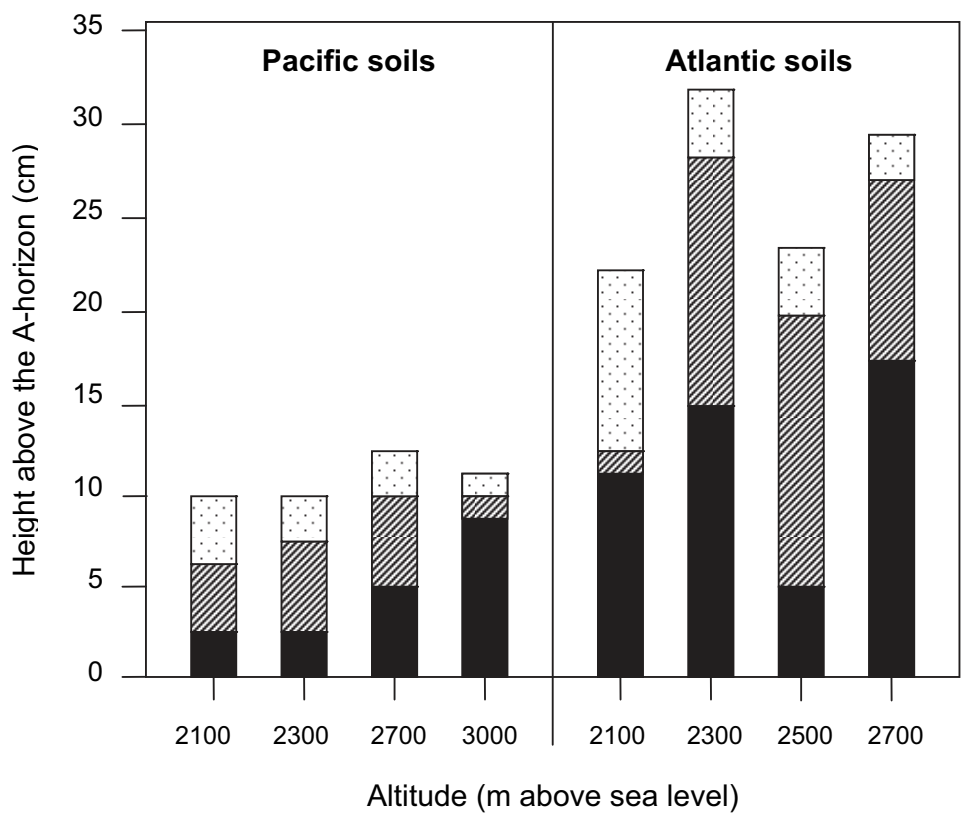

Fig. 4.3. Humus profiles of the 0 -horizon of old-growth oak forest soils found along an altitudinal gradient (2,100-3,000 m a.s.l.) at the Pacific and Atlantic slopes of the Chirripó National Park. Closed bars Humus horizon, dashed bars fermentation horizon, open bars litter horizon 
Ecological Studies Vol 185, Kappelle (Ed.) - page proofs by F. Kröner, HD

some mineral material. On the Atlantic slope, well-decomposed organic horizons are overlaid by less-decomposed horizons, and sometimes by litter layers (Fig. 4.3). On the Pacific slope, the well-decomposed organic horizon is overlaid by a horizon of about equal amounts of more or less fragmented litter and finely divided organic material. This horizon is overlaid by a litter layer. Humus profile thickness ranges from 10-40 $\mathrm{cm}$ (Atlantic slope) to $10-20 \mathrm{~cm}$ (Pacific slope). In lower parts of humus profiles, thick superficial root mats have been developed.

With increasing elevation along the Pacific slope (2,100-3,200 m a.s.l.), oak forest soils become more yellowish brown in color, with mineral soil material overlaid by layers of more sapric organic material, developed in sandy loams containing less weathered boulders but more fresh gravel and stones. Along this altitudinal gradient, the soil structure changes from very weathered, crumb-like, sub-angular blocky to less weathered and medium granular. At mid-elevation (2,300-2,700 $\mathrm{m}$ a.s.l.), dark gray eluvial horizons containing pure quartz grains may occur, and podsolization may take place. At all Pacific elevations, abundant roots traverse the organic soil material, which shows innumerous very fine and fine pores.

Soils along the Atlantic slope at 2,100 m a.s.l. are moderately deep and welldrained, and black to brownish yellow, overlaid by a 20 -cm-thick layer of fibric to sapric organic soil material. At 2,700 $\mathrm{m}$, soils are more shallow, imperfectly drained, very dark grayish brown to yellowish brown, with a dark gray, weakly developed, eluvial horizon, overlaid by a $30-\mathrm{cm}$-thick layer of fibric to sapric soil material. The organic layer thickness clearly peaks at mid-elevation (Fig. 4.3). Podsolization occurs at higher elevation. Along the Atlantic slope, mottles in the higher part of the soil profile are a result of accumulated organic matter (filled-up root spaces). Here, sandy loam is slightly sticky and plastic, and may contain rather high amounts of gravel. Larger roots may abound in the organic layer, and very fine to fine roots are common in the upper mineral horizons.

\subsection{Conclusions}

We conclude that climate factors and soil properties strongly influence forest structure, composition and diversity. Temperature seems to be the principal factor controlling the distribution of montane oak forest communities on Costa Rica's Chirripó Mountain. This observation is in line with conclusions drawn from studies on other tropical mountains (e.g., van der Hammen et al. 1983, 1989a; Kitayama and Mueller-Dombois 1994a, b; Vázquez and Givnish 1998; Ashton 2003; Kappelle 2004). Amounts and distribution of water vapor, nutrient availability, and light regime also play a major role in determining the forest structure and composition of montane forests on wet tropical 
Ecological Studies Vol 185, Kappelle (Ed.) - page proofs by F. Kröner, HD

Altitudinal Zonation of Montane Oak Forests Along Climate and Soil Gradients

mountains such as Chirripó. Observations at this oak-dominated mountain massif support the theory of a close correlation between the lower-upper montane forest ecotone and the diurnal cloud base, as previously documented by Grubb and Stevens (1985) for highland forests in Papua New Guinea. Ashton (2003) adds that the elevation of the diurnal cloud base is set by the relative humidity and rate of cooling of warm lowland air being conducted up slopes as it warms during the morning. This appears to be the case at Chirripó, too.

Climatic changes observed on Cerro Chirripó do not differ much from those found along altitudinal transects in Colombia (van der Hammen et al. 1983, 1989a). On Costa Rican as well as on Colombian neotropical mountains, the diurnal climate is much more pronounced than the yearly cycle. The average temperature in Chirripó's cool-humid montane oak forests depends principally on elevation, as temperature decreases with increasing altitude. A drop of $0.57^{\circ} \mathrm{C}$ per $100-\mathrm{m}$ increase in altitude is concordant with values estimated for other tropical mountains (Ohsawa et al. 1985; Walter 1985; Kitayama 1992). Sub-soil temperatures on Chirripó change with elevation, and reflect annual air temperatures.

Differences between hydrological regimes, as expressed in super-humid Atlantic slopes versus wet but seasonally marked Pacific slopes with a clear dry season, also play a crucial role in shaping montane forests in Costa Rica, similarly to other tropical mountains (Grubb 1977; Bruijnzeel et al. 1993; Bruijnzeel and Proctor 1995; Bruijnzeel and Veneklaas 1998). It is well known that average annual rainfall in tropical montane forests is correlated with slope orientation and fluctuates in the range $500-10,000 \mathrm{~mm}$, although yearly precipitation generally shows a range of only 1,000-3,000 $\mathrm{mm}$ (Kappelle 2004). Ascending air masses at windward slopes bring increased precipitation to mountain ridges where they cause the formation of condensation belts, especially at mid-elevations. This is particularly the case on Costa Rica's Atlantic slope, which is strongly influenced by trade winds coming in from the Caribbean Sea under influence of the Inter Tropical Convergence Zone (ITCZ; Kappelle 1992). Moreover, the net precipitation or throughfall in these montane cloud forests is significantly enhanced beyond rainfall contribution through direct canopy interception of cloud water (horizontal precipitation), a process also known as cloud stripping (Hölscher et al.2003, 2005, and Chap. 21). It is therefore not surprising that these magnificent oak forests are particularly rich in epiphytes, which directly obtain water from the perhumid atmosphere (Hölscher et al. 2003, and Chaps. 6, 7, 21 and 29).

Edaphic changes occurring in Costa Rica's montane oak forests appear to be strongly correlated to climate. The yellowish and acid soils on the wetter Atlantic slope are covered with thicker layers of organic material, sometimes even forming peat. Frequently, organic matter becomes more admixed with mineral soil below, and penetrates to greater depth in the soil profile, as has also been noted on Asian mountains (Whitmore and Burnham 1969; Ashton 
2003). Such clay-rich soils show crumb structures resembling temperate loams, as Ashton (2003) clearly states. On Chirripó, like on other tropical mountains (Vitousek and Sanford 1986; Tanner et al. 1998; Silver et al. 2001), soils are often waterlogged and suffer from podsolization (van Uffelen 1991), a soil-forming process that causes the leaching of nutrients (lixiviation) from upper soil horizons to lower levels. These nutrient-poor, water-saturated soils may experience an anaerobic environment, associated with impeded root respiration, a reduction in belowground bioactivity, lower decomposition levels, subsequent lower rates of nutrient cycling, and reduced nutrient availability (Vitousek and Sanford 1986; Cuevas and Medina 1988; Tanner et al. 1998; Silver et al.2001, and Chap. 22). As a result, humus accumulates in top soils (histic horizons, histosols), and nutrients are lost at top and mid soil levels (podsols). In conjunction with this, lowered mineralization rates may lead to larger fine root systems (Chap. 22). All these soil properties appear to correlate strongly with oak forest community distribution (Kappelle et al. 1995a).

The thickness of the humus profile on Chirripó's montane slopes is highest between 2,300 and 2,700 $\mathrm{m}$ a.s.l., probably as a consequence of low temperatures, which account for a low degree of soil bioactivity and subsequently slow decomposition processes. With respect to organic carbon levels, soils at Chirripó are similar to those on mountains in New Guinea or Jamaica (Edwards and Grubb 1977, 1982; Tanner 1977). Regarding exchangeable elements (bases), soils at Chirripó are somewhat poorer than their equivalents in Jamaica or Borneo (Tanner 1977; Kitayama 1992), but close to values measured along the La Selva-Barva Volcano altitudinal transect in Costa Rica (Marrs et al. 1988). However, contents of Ca and extractable P resemble those recorded for Mt. Kinabalu (Kitayama 1992).

Acknowledgements Numerous plant taxonomists helped with species identification; their invaluable support is gratefully acknowledged. Major funding was provided by NWO-WOTRO, the University of Amsterdam, and Costa Rica's National University and Biodiversity Institute. Research permission was provided by MINAE.

\section{References}

Aiba S, Kitayama K (1999) Structure, composition and species diversity in an altitudesubstrate matrix of rain forest tree communities on Mount Kinabalu, Borneo. Plant Ecol 140:139-157

Ashton P (2003) Floristic zonation of tree communities on wet tropical mountains revisited. Perspect Plant Ecol Evol Syst 6(1/2):87-104

Blaser J (1987) Standörtliche und waldkundliche Analyse eines Eichen-Wolkenwaldes (Quercus spp.) der Montanstufe in Costa Rica. PhD Thesis, Georg-August Universität, Göttingen 
Ecological Studies Vol 185, Kappelle (Ed.) - page proofs by F. Kröner, HD

Altitudinal Zonation of Montane Oak Forests Along Climate and Soil Gradients

Braun-Blanquet J (1965) Plant sociology: the study of plant communities. Hafner, London

Bruijnzeel LA, Proctor J (1995) Hydrology and biogeochemistry of tropical montane cloud forests: what do we really know? In: Hamilton LS, Juvik JO, Scatena FN (eds) Tropical montane cloud forests. Springer, Berlin Heidelberg New York, Ecological Studies 110, pp 38-78

Bruijnzeel LA, Veneklaas EJ (1998) Climatic conditions and tropical montane forest productivity: the fog has not lifted yet. Ecology 79(1):3-9

Bruijnzeel LA, Waterloo MJ, Proctor J, Kuiters AT, Kotterink B (1993) Hydrological observations in montane rain forests on Gunung Silam, Sabah, Malaysia, with special reference to the „Massenerhebung“ effect. J Ecol 81:145-167

Cuatrecasas J (1934) Observaciones geobotánicas en Colombia. Trab Mus Nac Cienc Nat Ser Bot 27:1-144

Cuatrecasas J (1958) Aspectos de la vegetación natural de Colombia. Rev Acad Col Cienc Exac Fís Nat 10(40):221-268

Cuevas E, Medina E (1988) Nutrient dynamics within Amazonian forests. II. Fine root growth, nutrient availability and leaf litter decomposition. Oecologia 76:222-235

Edwards PJ, Grubb PJ (1977) Studies on mineral cycling in a montane rain forest in New Guinea. I. The distribution of organic matter in the vegetation and soil. J Ecol 65:943-969

Edwards PJ, Grubb PJ (1982) Studies on mineral cycling in a montane rain forest in New Guinea. II. Soil characteristics and the division of mineral elements between the vegetation and soil. J Ecol 70:649-666

Ellenberg H (1975) Vegetationsstufen in perhumiden bis perariden Bereichen der tropischen Anden. Phytocoenology 2:368-387

FAO (1977) Guidelines for soil profile descriptions. UN Food and Agricultural Organization, Rome

FAO (1988) Soil map of the World with revised legend. UN Food and Agricultural Organization, Rome, World Soil Resources Rep 60

Flenley JR (ed) (1974) Altitudinal zonation of forests in Malesia. Trans 3rd AberdeenHull Symp Malesian Ecology, University of Hull, Hull. Dep Miscell Ser 16

Gentry AH (1988) Changes in plant community diversity and floristic composition on environmental and geographical gradients. Ann Missouri Bot Gard 75:1-34

Grubb PJ (1977) Control of forest growth and distribution on wet tropical mountains: with special reference to mineral nutrition. Annu Rev Ecol Syst 8:83-107

Grubb PJ, Stevens PF (1985) The forests of the Fatima Basin and Mt. Kerigomna, Papua New Guinea, with a review of montane and subalpine rain forests in Papuasia. Australian National University, Canberra, Publ BG/5

Grubb PJ, Whitmore TC (1966) A comparison of montane and lowland rain forest in Ecuador. II. The climate and its effects on the distribution and physiognomy of the forests. J Ecol 54:303-333

Holdridge LR, Grenke WC, Hatheway WH, Liang T, Tosi JA (1971) Forest environments in tropical life zones. Pergamon Press, Oxford

Hölscher D, Köhler L, Leuschner C, Kappelle M (2003) Nutrient fluxes in stemflow and throughfall in three successional stages of an upper montane rain forest in Costa Rica. J Trop Ecol 19:557-565

Hölscher D, Köhler L, Leuschner C, Kappelle M (2005) Ecology and use of old-growth and recovering montane oak forest in the Cordillera de Talamanca, Costa Rica. In: Juvik J, Bruijnzeel LA (eds) Mountains in the mist: science for conserving and managing tropical montane cloud forests. University of Hawaii Press, Honolulu (in press)

Ecological Studies Vol 185, Kappelle (Ed.) - page proofs by F. Kröner, HD 
Ecological Studies Vol 185, Kappelle (Ed.) - page proofs by F. Kröner, HD

Holz I, Gradstein SR, Heinrichs J, Kappelle M (2002) Bryophyte diversity, microhabitat differentiation and distribution of life forms in Costa Rican upper montane Quercus forest. Bryologist 105(3):334-348

Islebe GA, Kappelle M (1994) A phytogeographical comparison between subalpine forests of Guatemala and Costa Rica. Feddes Rep 105(1/2):73-87

Jongman RHG, Ter Braak CJF, van Tongeren OFR (eds) (1987) Data analysis in community and landscape ecology. Pudoc, Wageningen

Kappelle M (1991) Distribución altitudinal de la vegetación del Parque Nacional Chirripó, Costa Rica. Brenesia 36:1-14

Kappelle M (1992) Structural and floristic differences between wet Atlantic and moist Pacific montane Myrsine-Quercus forests in Costa Rica. In: Balslev H, Luteyn JL (eds) Páramo: an Andean ecosystem under human influence. Academic Press, London, pp 61-70

Kappelle M (1996) Los bosques de roble (Quercus) de la Cordillera de Talamanca, Costa Rica: biodiversidad, ecología, conservación y desarrollo. Instituto Nacional de Biodiversidad (INBio), Santo Domingo de Heredia, Costa Rica

Kappelle M (2004) Tropical montane forests. In: Burley J, Evans J, Youngquist JA (eds) Encyclopedia of Forest Sciences, vol 4. Elsevier, Oxford, UK, pp 1782-1793

Kappelle M, Gómez LD (1992) Distribution and diversity of montane pteridophytes of the Chirripó National Park, Costa Rica. Brenesia 37:67-77

Kappelle M, Horn SP (eds) (2005) Páramos de Costa Rica. Instituto Nacional de Biodiversidad (INBio), Santo Domingo de Heredia, Costa Rica

Kappelle M, Sipman HJM (1992) Foliose and fruticose lichens of Talamanca montane Quercus forests, Costa Rica. Brenesia 37:51-58

Kappelle M, Zamora N (1995) Changes in woody species richness along an altitudinal gradient in Talamancan montane Quercus forests, Costa Rica. In: Churchill SP, Balslev $\mathrm{H}$, Forero E, Luteyn JL (eds) Biodiversity and conservation of Neotropical montane forests. New York Botanical Garden Press, Bronx, NY, pp 135-148

Kappelle M, Cleef AM, Chaverri A (1989) Phytosociology of montane Chusquea-Quercus forests, Cordillera de Talamanca, Costa Rica. Brenesia 32:73-105

Kappelle M, Zamora N, Flores T (1991) Flora leñosa de la zona alta (2000-3819 m) de la Cordillera de Talamanca, Costa Rica. Brenesia 34:121-144

Kappelle M, van Velzen HP, Wijtzes WH (1994) Plant communities of montane secondary vegetation in the Cordillera de Talamanca, Costa Rica. Phytocoenology 22(4):449-484

Kappelle M, van Uffelen JG, Cleef AM (1995a) Altitudinal zonation of montane Quercus forests along two transects in the Chirripó National Park, Costa Rica. Vegetatio 119:119-153

Kappelle M, Kennis PAF, de Vries RAJ (1995b) Changes in diversity along a successional gradient in a Costa Rican upper montane Quercus forest. Biodiv Conserv 4:10-34

Kappelle M, van Omme E, Juárez ME (2000) Lista de la flora vascular terrestre de la cuenca superior del Río Savegre, San Gerardo de Dota, Costa Rica. Acta Bot Mex 51:1-38

Kitayama K (1992) An altitudinal transect study of the vegetation of Mount Kinabalu, Borneo. Vegetatio 102:149-171

Kitayama K, Aiba S (2002) Ecosystem structure and productivity of tropical rain forests along altitudinal gradients with contrasting soil $\mathrm{P}$ pools on Mount Kinabalu, Borneo. J Ecol 90:37-51

Kitayama K, Mueller-Dombois D (1994a) An altitudinal transect analysis of the windward vegetation on Haleakala, a Hawaiian mountain: (1) climate and soils. Phytocoenology 24:111-133 
Ecological Studies Vol 185, Kappelle (Ed.) - page proofs by F. Kröner, HD

Altitudinal Zonation of Montane Oak Forests Along Climate and Soil Gradients

Kitayama K, Mueller-Dombois D (1994b) An altitudinal transect analysis of the windward vegetation on Haleakala, a Hawaiian mountain: (2) Vegetation zonation. Phytocoenology 24:135-154

Lauer W (1976) Zur Hygrischen Höhenstufung Tropischer Gebirge. In: Sioli H (ed) Neotropische Ökosysteme. Biogeographica 7:169-182

Leuschner C (2000) Are high elevations in tropical mountains arid environments for plants? Ecology 81:1425-1436

Lieberman D, Lieberman M, Peralta R, Hartshorn GS (1996) Tropical forest structure and composition on a large-scale altitudinal gradient in Costa Rica. J Ecol 84:137-152

Marrs RH, Proctor J, Heaney A, Mountford MD (1988) Changes in soil nitrogen - mineralization and nitrification along an altitudinal transect in tropical rainforest in Costa Rica. J Ecol 76:466-482

Mueller-Dombois DR, Ellenberg H (1974) Aims and methods of vegetation ecology. Wiley, New York, NY

Ohsawa M, Nainggolan PHJ, Tanaka N, Anwar C (1985) Altitudinal zonation of forest vegetation on Mount Kerinci, Sumatra: with comparisons to zonation in the temperate region of East Asia. J Trop Ecol 1:193-216

Oosterhoorn M, Kappelle M (2000) Vegetation structure and composition along an interior-edge-exterior gradient in a Costa Rican montane cloud forest. For Ecol Manage 126:291-307

Pendry CA, Proctor J (1997) Altitudinal zonation of rain forest on Bukit Belalong, Brunei: soils, forest structure and floristics. J Trop Ecol 13:221-241

Sevink J (1984) An altitudinal sequence of soils in the Sierra Nevada de Santa Marta. In: Van der Hammen T, Ruiz PM (eds) La Sierra Nevada de Santa Marta (Colombia), transecto Buritaca - La Cumbre. Cramer, Vaduz, Liechtenstein, Studies in Tropical Andean Ecosystems, vol 2, pp 131-138

Silver WL, Marín-Spiotta E, Lugo AE (2001) El Caribe. In: Kappelle M, Brown AD (eds) Bosques nublados del Neotrópico. World Conservation Union (IUCN) - Instituto Nacional de Biodiversidad (INBio), Santo Domingo de Heredia, Costa Rica, pp 155-181

Tanner EVJ (1977) Four montane rain forests of Jamaica: a quantitative characterization of the floristics, the soils and the foliar mineral levels, and a discussion of the interrelations. J Ecol 65:883-918

Tanner EVJ, Vitousek PM, Cuevas E (1998) Experimental investigation of nutrient limitation of forest growth on wet tropical mountains. Ecology 79:10-22

Van der Hammen T, Preciado AP, Pinto P (eds) (1983) La Cordillera Central Colombiana, transecto Parque Los Nevados (introducción y datos iniciales). Cramer, Vaduz, Liechtenstein, Studies in Tropical Andean Ecosystems, vol 1

Van der Hammen T, Diaz S, Álvarez VJ (eds) (1989a) La Cordillera Central Colombiana, transecto Parque Los Nevados (segunda parte). Cramer, Berlin, Studies in Tropical Andean Ecosystems, vol 3

Van der Hammen T, Mueller-Dombois D, Little MA (1989b) Manual of methods for mountain transect studies. International Union of Biological Sciences (IUBS), Paris

Van Uffelen JG (1991) A geological, geomorphological and soil transect study of the Chirripó Massif and adjacent areas, Cordillera de Talamanca, Costa Rica. MSc Thesis, Wageningen Agricultural University, Wageningen, The Netherlands

Vázquez JA, Givnish TJ (1998) Altitudinal gradients in tropical forest compositon, structure, and diversity in the Sierra de Manantlán. J Ecol 86:999-1020

Vitousek PM, Sanford RL (1986) Nutrient cycling in moist tropical forest. Annu Rev Ecol Syst 17:137-167

Vitousek PM, Turner DR, Kitayama K (1995a) Foliar nutrients during long-term soil development in Hawaiian montane rain forest. Ecology 76:712-720 
Ecological Studies Vol 185, Kappelle (Ed.) - page proofs by F. Kröner, HD

Vitousek PM, Gerrish G, Turner DR, Walker LR, Mueller-Dombois D (1995b) Litterfall and nutrient cycling in four Hawaiian montane rainforests. J Trop Ecol 11:189-203

Von Humboldt A, Bonpland A (1808) Personal narrative of travels to the equinoctial regions of the new continent during the years 1799-1804, vols 1-6. Longman Hurst and Rees, London

Walter H (1985) Vegetation of the earth and ecological systems of the geobiosphere. Springer, Berlin Heidelberg New York

Whitmore TC, Burnham CP (1969) The altitudinal sequence of forests and soils on granite near Kuala Lumpur. Malay Nat J 22:99-118 